\title{
Optimal Coupling Combinations between Irrigation and Seeding Rates for Improving Production and Water Use Efficiency of Wheat Grown under Arid Conditions
}

\author{
Salah, E. El-Hendawy ${ }^{1,2}$ \\ ${ }^{1}$ Department of Plant Production, College of Food and Agriculture Sciences, King Saud University, 11451 Riyadh, Saudi Arabia \\ ${ }^{2}$ Agronomy Department, Faculty of Agriculture, Suez Canal University, 41522 Ismailia, Egypt
}

Received: $1 / 3 / 2016$

\begin{abstract}
The sustainable use of water is becoming increasingly important for food security in arid and semi-arid regions with limited water resources. This study was conducted to determine the optimal coupling combinations between irrigation and seeding rates in order to achieve the high grain yield and efficient irrigation water use simultaneously for wheat grown under arid conditions. The experiment was conducted during 2013/2014 and $2014 / 2015$ growing seasons to study the effect of three irrigation rates i.e. $1.00,0.75$, and 0.50 of the estimated evapotranspiration (ET) and five seeding rates i.e. 150, 250, 350, 450 and 550 seeds $/ \mathrm{m}^{2}$ on yield components, grain yield and irrigation water use efficiency (IWUE). The results indicated that grain yield and yield components of Sakha 94 were gradually decreased by decreasing irrigation rates and increasing seeding rates. The values of IWUE and harvest index were decreased also by decreasing irrigation rate, while the highest values for both traits were achieved at 350 seeds $/ \mathrm{m}^{2}$. The seeding rate of 350 and $250 \mathrm{seeds} / \mathrm{m}^{2}$ were most effective to obtain the lowest value for seasonal yield response factors under 0.75 and $0.50 \mathrm{ET}$, respectively. Based on the production functions of grain yield versus seeding rates for each irrigation rate, the optimum seeding rate for the maximum grain were 411 and $425 \mathrm{seeds} / \mathrm{m}^{2}$ for $1.00 \mathrm{ET}, 362$ and $378 \mathrm{seeds} / \mathrm{m}^{2}$ for $0.75 \mathrm{ET}$ and 315 and 350 seeds $/ \mathrm{m}^{2}$ for 0.50 ET in the first and second season, respectively.
\end{abstract}

Keywords: Deficit irrigation, harvest index, water production functions, yield response factor.

\section{INTRODUCTION}

Water shortages currently pervade almost every country in arid and semi-arid regions and recently become the basic norm rather than the exception in these regions. Another worrying fact is that the shortage water in these regions is further worsened by abrupt climate change and population growth. Therefore, water shortage events have gained increasing importance in both the scientific and political agendas. Because the agricultural sector is the major consumer of water supply, thus the sustainable use of water resources and increase water use efficiency (WUE) in this sector is becoming necessary to face this challenge. In this situation, it is important to apply some targeted activities in order to decrease the amount of water used for crop production.

Strategic options for improving WUE in crop production sector include improving land husbandry, developing of drought tolerant genotypes, and applying special agronomic practices (Richards, 2004; Boutraa, 2010). While further genetic enhancement and soil management may need many efforts over several years to get sensible results, applied suitable agronomic practices will give the most immediate, economic and effective way to improve irrigation WUE in crop production sector (Singh et al., 2010). Generally, the improvement of WUE at field scale is expected to depend equally on applying the best agronomic practices and using the drought tolerant genotypes (Passioura, 2006). For example, Morison et al. (2008) reported that, in the water-scarce environments, about half of yield improvements related to improvements in genetic potential and the other half related to apply of the best agronomic practices. Most importantly, the vital role of genetic potential in improving WUE can only be achieved if the appropriate agronomic practices are also be coupled simultaneously. From this point of view, we can say that the role of agronomic practices in improving irrigation WUE in crop production sector might be effective as well as we can rely basically on these practices in order to achieve our goal for conservation agricultural water.

Deficit irrigation strategy is one of the agronomic practices has been suggested in arid and semi-arid regions in order to achieve the goal of reducing irrigation water use in the agriculture sector. With this strategy, the crops are irrigated with an amount of water less than their requirements during the whole or specific phenological stages of crop cycle (Fereres and Soriano, 2007). Because the grain yield of $C_{3}$ plants such as wheat is linearly correlated with the crop evapotranspiration, thus it is difficult to apply the deficit irrigation strategy for wheat production without an accompanying reduction in the final grain yield. For instance, Mugabe and Nyakatawa (2000) reported that the reduction in final grain yield of wheat crop under 75 and $50 \%$ of crop water requirements were an average for 2-years studies of 12 and $20 \%$, respectively. However, on the other hand, the water deficit strategy increases the WUE by maximizing the production per unit of water consumed rather than emphasizing production per unit area. Numerous studies have reported that the WUE of cereal crops such as wheat, maize and rice increased by 10 to $42 \%$ under water deficit conditions as compared with normal irrigation (Xue et al., 2006; Soundharajan and Sudheer, 2009; Li et al., 2010; M'hamed et al., 2015).

The reduction in the final grain yield of wheat under water deficit strategy is caused by a reduction in many yield components especially the number of spikes per square meter, the number of grains per spike and the 
weight of single grain. For instance, Zhong-hu and Rajaran (1994) and Passioura and Angus (2010) reported that spike number per square meter, grain number per spike and sometimes grain weight were the most sensitive yield components to water deficit particularly when it apply this strategy around anthesis and during grain-filling growth stages. Therefore, applying water deficit strategy needs to be coupled with other agronomic practice to compensate the adverse effects of water deficit on important yield components.

Interesting, the most yield components that negatively affected by water deficit are able to compensate for one another in order to stabilize yield. Therefore, numerous studies have demonstrated that seeding rate is one of the suitable agronomic practices that might play a complementary role with water deficit strategy in order to improve yield and WUE simultaneously. In addition, seeding rate is a particular importance in wheat production because it is under the farmer's control in most cropping system. In general, high seeding rate in wheat increase the number of spikes per square meter, but decrease the number of spikes per plant and grain weight per spike, whereas the opposite occurs with low seeding rate (Arduini et al., 2006; Chen et al., 2008; Seleiman et al., 2010; Naseri et al., 2012; Valério et al., 2013). Whaley et al. (2000) reported that the decrease of seeding rate in wheat from 338 to only 19 seeds $/ \mathrm{m}^{2}$ increased number of grains per spike by $50 \%$. The grain number per spike increased by only $10 \%$ in other study, when seeding rate was decreased from 625 to 325 seeds $/ \mathrm{m}^{2}$ (Ozturk et al., 2006). Tompkins et al. (1991) found that number of spike per square meter increased when seeding rate was increased from 65 to $400 \mathrm{seeds} / \mathrm{m}^{2}$. Ali et al., (2004) also reported that increase seeding rate from 300 to 400 and 500 seeds $/ \mathrm{m}^{2}$ significantly increased number of spikes per square meter, whereas grain weight per spike and individual grain weight were significantly decreased. Therefore, the proper matching between seeding rate and water deficit is essential for a successful production of wheat crop under arid conditions. The manipulation of seeding rate under deficit irrigation treatments could exert great impact on final grain yield of wheat. In general, the best seeding rate under deficit irrigation is that which maximizes grain yield and irrigation WUE simultaneously.

From the management point of view, it can conclude that the responses of final grain yield of wheat for seasonal ET is linear, whereas it was quadratic for seeding rate. In light of this facts, the objectives of this study were: (1) to determine the impacts of irrigation and seeding rates on wheat production and WUE, and (2) to establish the optimum coupling combinations between irrigation and seeding rates in order to achieve maximum yield and IWUE for wheat grown under either sufficient or deficit water application.

\section{MATERIALS AND METHODS}

\section{Experimental conditions and design}

This study was performed during 2013/2014 and 2014/2015 growing seasons in Dierab Research Station of the College of Food and Agriculture Sciences, King
Saud University, Riyadh, Saudi Arabia $\left(24^{\circ} 25^{\prime} \mathrm{N}\right.$, $46^{\circ} 34^{\prime} \mathrm{E}, 400 \mathrm{~m}$ a.s.1.). Climate of Derab is characterized by a typical arid climate. Mean precipitation and daily temperature during the growing cycle of wheat (from December until May) are about $17 \mathrm{~mm}$ and $19.7{ }^{\circ} \mathrm{C}$, respectively. The texture of the experimental soil is sandy throughout its profile $(92.8 \%$ sand, $4.5 \%$ silt and $2.7 \%$ clay) with a bulk density, field capacity, and permanent wilting point in a $0-60 \mathrm{~cm}$ surface layer of $1.48 \mathrm{~g} \mathrm{~cm}^{-3}, \quad 0.094 \mathrm{~m}^{3} \mathrm{~m}^{-3}$ and $0.034 \mathrm{~m}^{3} \mathrm{~m}^{-3}$, respectively.

In both seasons, the experiment was set in a randomized complete block split plot design with three replicates. Different treatments of irrigation water and seeding rates were randomly assigned to the main plots and subplots, respectively. Each subplot consisted of six rows with a length of $6.0 \mathrm{~m}$ and spaced $0.20 \mathrm{~m}$ apart (a plot area equal $7.2 \mathrm{~m}^{2}$ ). There was a $1 \mathrm{~m}$ between the adjacent subplots and $3 \mathrm{~m}$ between the main plots in order to control irrigation. Seeds of Sakha 94 were planted on December $1^{\text {th }} 2013$ and November $28^{\text {th }} 2014$. Nitrogen fertilizer was applied at a rate of $120 \mathrm{~kg} \mathrm{ha}^{-1}$ of $\mathrm{N}$ in three equal doses at sowing, beginning of tillering and beginning of booting stages. Phosphorus fertilizer was applied at a rate of $31 \mathrm{~kg} \mathrm{ha}^{-1} \mathrm{P}_{2} \mathrm{O}_{5}$ prior to sowing. Other agronomic practices such as protected wheat plants from weeds and diseases were done in a timely manner.

\section{Experimental treatments}

Three irrigation water rates $\left(\mathrm{I}_{1}: 1.00, \mathrm{I}_{2}: 0.75\right.$ and $\mathrm{I}_{3}$ : 0.50 of the estimated crop evapotranspiration, ET), which represented $625.0,468.75$ and $312.50 \mathrm{~mm} / \mathrm{ha}$ of water, respectively, were applied by surface irrigation. To deliver constant and equal amounts of water to each plot, the main line of surface irrigation which delivers the water from water source to plot was distributed to the sub-main hoses at each plot and equipped with manual control valves. To calculate the amount of water applied for each irrigation treatment, a flow meter was connected where the water passing from the source of water to the main line of surface irrigation. The surface irrigation was applied eight times during the growing season. The time of irrigation and the quantities of water applied at each time for each treatment are given in Table (1). The phenological stages where irrigation are applied were determined based on Zadoks' decimal code of growth stages (Zadoks et al., 1974).

The amount of irrigation water applied for each irrigation in $\mathrm{mm} \mathrm{ha}^{-1}$ was calculated according to the daily reference evapotranspiration $\left(\mathrm{ET}_{\mathrm{O}}\right)$ and the crop coefficient $\left(\mathrm{K}_{\mathrm{C}}\right)$. The $\mathrm{ET}_{\mathrm{O}}$ was computed using the Penman-Monteith method (Allen et al., 1998) and the daily climatic data obtained from the agrometeorological station adjacent to experimental location. The FAO Kc values that suggested by FAO-56 (Allen et al., 1998) for wheat crop was used. Because these values of FAO Kc are suggested for sub-humid climate conditions with a minimum relative humidity of $45 \%$ and moderate wind speed of about $2 \mathrm{~m} / \mathrm{s}^{1}$, the FAO Kc values were adjusted according to the local values for minimum relative humidity and wind speed and maximum plant height. 
Five seeding rates $(150,250,350,450$ and 550 seeds $/ \mathrm{m}^{2}$ ), which included two densities above and below the standard of densities for wheat crop, were randomly nested within each main plot of irrigation treatments as a split plot. With germination percentage of $95 \%$ and 1000 -grain weight of $45.0 \mathrm{~g}$, the seeding rates of $150,250,350,450$ and 550 seeds $/ \mathrm{m}^{2}$ equal to $71.0,118.0,165.0,213.0$ and $260.0 \mathrm{~kg}$ seeds/ha, respectively.

Table (1): The time of each irrigation event and quantity of water applied for each irrigation treatment (data averaged over two seasons).

\begin{tabular}{lccc}
\hline \multirow{2}{*}{ Growth stage } & \multicolumn{3}{c}{ Quantity of water applied (mm/ha) } \\
\cline { 2 - 4 } & $\mathbf{I}_{\mathbf{1}} \mathbf{( 1 . 0 0 ~ E T )}$ & $\mathbf{I}_{\mathbf{2}}(\mathbf{0 . 7 5} \mathbf{E T})$ & $\mathbf{I}_{\mathbf{3}} \mathbf{( \mathbf { 0 . 5 0 } \text { ET) }}$ \\
\hline Seedling (ZS 24) & 65.00 & 48.75 & 32.50 \\
Tillering (ZS 24) & 75.00 & 56.25 & 37.50 \\
Stem elongation (ZS 32) & 75.00 & 56.25 & 37.50 \\
Booting (ZS 49) & 85.00 & 63.75 & 42.50 \\
Heading (ZS 59) & 85.00 & 63.75 & 42.50 \\
Anthesis (ZS 68) & 90.00 & 67.50 & 45.00 \\
Grain milk (ZS 73) & 75.00 & 56.25 & 37.50 \\
Grain dough (ZS 83) & 75.00 & 56.25 & 37.50 \\
\hline Total (mm ha $\left.{ }^{-1}\right)$ & $\mathbf{6 2 5 . 0 0}$ & $\mathbf{4 6 8 . 7 5}$ & $\mathbf{3 1 2 . 5 0}$ \\
\hline
\end{tabular}

"ZS means Zadoks' decimal code of growth stages

\section{Measurements}

At maturity, twenty guarded plants were removed from each plot and measured for plant height, number of tillers and spikes per plant, number of grains per spike and weight of a thousand grains. The thousand grain weight was calculated from the average weight of five sets of 1000 grains. The total of grain yield per hectare was determined by hand harvesting an area of four rows $4.0 \mathrm{~m}$ in length $\left(3.2 \mathrm{~m}^{2}\right)$. Before threshing the bundles of harvested area, the bundles were weighed in order to calculate the biological yield and then threshed using a plot combine. The grain yield was calculated based on $15 \%$ moisture content at harvest.

Harvest index (HI) was calculated by dividing the weight of grain yield by the weight of biological yield and was expressed in percent. Irrigation water use efficiency (IWUE) was calculated by dividing the weight of grain yield from a given irrigation treatment and seeding rate $(\mathrm{kg} / \mathrm{ha})$ by the amount of applied irrigation water for each irrigation treatment ( $\mathrm{mm} / \mathrm{ha})$.

\section{Yield response factor $\left(k_{\mathbf{y}}\right)$}

The $\mathrm{k}_{\mathrm{y}}$ values, which represent the relationship between the relative yield reduction $\left(1-\mathrm{Y}_{\mathrm{a}} / \mathrm{Y}_{\mathrm{m}}\right)$ and relative $\mathrm{ET}$ deficit $\left(1-\mathrm{ET}_{\mathrm{a}} / \mathrm{ET}_{\mathrm{m}}\right)$, for each seeding rate at 0.75 and 0.50 ET treatments were calculated using the following formula (Doorenbos and Kassam 1979):

$$
\left(1-\frac{Y a}{Y m}\right)=k_{y}\left(1-\frac{E T a}{E T m}\right)
$$

Where $\mathrm{Ya}, \mathrm{Y}_{\mathrm{m}}, \mathrm{ET}_{\mathrm{a}}$ and $\mathrm{ET}_{\mathrm{m}}$ represent the actual and maximum of grain yields (Y) and seasonal crop evapotranspiration (ET), respectively. The highest grain yield under $1.00 \mathrm{ET}$ and the amount of irrigation water applied for also 1.00 ET were assumed as the corresponding maximum $\mathrm{Y}_{\mathrm{m}}$ and $\mathrm{ET}_{\mathrm{m}}$, respectively. Whereas, the grain yield and the amount of irrigation water applied at the combinations of 0.75 and $0.50 \mathrm{ET}$ with different seeding rates were assumed as the actual grain yield (Ya) and actual evapotranspiration (ETa), respectively.

\section{Statistical analysis}

Data were tested using a split-plot design and the irrigation water amounts and seeding rates were considered fixed effects. The statistical analysis was performed by CoStat system for Windows, version 6.311 (CoHort software, Berkeley, CA 94701). The differences among the treatment means were compared by using Duncan's multiple test at 95\% levels of probability. Regression analysis was performed to investigate the relationship between yield and ET and the best relationship between yield and seeding rates. The regression analyses were performed by Sigma Plot 8.0 (Systat software, Inc., San Jose, CA, USA). 


\section{RESULTS AND DISCUSSION}

\section{Yield components and grain yield}

In general, all studied yield components and grain yield were gradually decreased by decreasing irrigation rates (Tables 2 and 3). Averaged over the two growing seasons, the decreases in yield components and grain yield at 0.75 and 0.50 ET were 11.8 and $27.1 \%$ for plant height, 18.9 and $38.0 \%$ for tiller number per plant, 16.1 and $39.7 \%$ for spike number per plant, 10.6 and $31.8 \%$. for grain number per spike, 6.4 and $23.5 \%$ for 1000 grain weight, and 27.4 and $59.3 \%$ for grain yield per hectare, respectively, when compared with 1.00 ET treatment (Tables 2 and 3). These results indicate that wheat crop is very sensitive for water shortage and it is difficult exposing wheat plants to deficit irrigation without expecting reduction in grain yield and its components. These results are in agreement with earlier studies reporting that in order to obtain the maximum production for wheat crop, the amount of water applied should be sufficient to meet the water requirement of the plants at different growth stages (Zhang et al., 2006; Ali et al., 2007; Karam et al., 2009). The reduction in grain yield and its components with decreasing irrigation rate may be due to the increase of total resistance in the soil-plant system leads to change in patterns of plant growth and development, and disturbance metabolites transportation to the grains (Kramer and Boyer 1995; Ouda 2006). Whereas, applied of sufficient irrigation water might help plant to absorb their need from water and nutrients (Ramadan and Awaad; 2008).

Table (2): Effects of irrigation rate, seeding rate and their interactions on selected yield components in two growing seasons.

\begin{tabular}{|c|c|c|c|c|c|c|c|c|}
\hline \multirow{3}{*}{$\begin{array}{l}\text { Seeding rates } \\
\left(\operatorname{seeds} / \mathbf{m}^{2}\right)\end{array}$} & \multicolumn{4}{|c|}{$2013 / 2014$} & \multicolumn{4}{|c|}{$2014 / 2015$} \\
\hline & \multicolumn{8}{|c|}{ Irrigation rates } \\
\hline & $\begin{array}{c}1.00 \text { ET } \\
\left(I_{1}\right)\end{array}$ & $\begin{array}{c}\text { 0.75ET } \\
\left(\mathbf{I}_{2}\right)\end{array}$ & $\begin{array}{c}0.50 \text { ET } \\
\left(I_{3}\right)\end{array}$ & Mean & $\begin{array}{c}1.00 \text { ET } \\
\left(\mathbf{I}_{1}\right)\end{array}$ & $\begin{array}{c}\text { 0.75ET } \\
\left(\mathbf{I}_{2}\right)\end{array}$ & $\begin{array}{c}0.50 \text { ET } \\
\left(\mathbf{I}_{3}\right)\end{array}$ & Mean \\
\hline \multicolumn{9}{|c|}{ Plant height (cm) } \\
\hline 150 & $97.0 \mathrm{abc}$ & $103.0 \mathrm{ab}$ & $89.7 \mathrm{c}$ & $96.6 \mathrm{a}$ & $93.7 \mathrm{abc}$ & $100.7 \mathrm{ab}$ & $84.0 \mathrm{c}$ & $92.8 \mathrm{a}$ \\
\hline 250 & $99.7 \mathrm{ab}$ & $96.3 \mathrm{bc}$ & $78.0 \mathrm{~d}$ & $91.3 \mathrm{~b}$ & $93.7 \mathrm{abc}$ & 89.7 bc & $76.7 \mathrm{c}$ & $86.7 \mathrm{~b}$ \\
\hline 350 & $103.0 \mathrm{ab}$ & $87.0 \mathrm{c}$ & $71.3 \mathrm{e}$ & 87.1 c & $100.7 \mathrm{ab}$ & 89.7 bc & $71.0 \mathrm{~d}$ & 87.1 b \\
\hline 450 & $106.7 \mathrm{a}$ & $80.3 \mathrm{~d}$ & $68.0 \mathrm{f}$ & $85.0 \mathrm{~cd}$ & $100.3 \mathrm{ab}$ & $81.3 \mathrm{c}$ & $67.3 \mathrm{~d}$ & $83.0 \mathrm{~b}$ \\
\hline 550 & $105.7 \mathrm{a}$ & $78.0 \mathrm{~d}$ & $66.0 \mathrm{f}$ & $83.2 \mathrm{~d}$ & $104.7 \mathrm{a}$ & $80.7 \mathrm{c}$ & $60.3 \mathrm{e}$ & $81.9 \mathrm{~b}$ \\
\hline Mean & 102.4 a & 88.9 b & $74.6 \mathrm{c}$ & & 98.6 a & $88.4 \mathrm{~b}$ & $71.9 \mathrm{c}$ & \\
\hline \multicolumn{9}{|c|}{ Number of tillers per plant } \\
\hline 150 & $6.3 \mathrm{a}$ & $5.6 \mathrm{a}$ & $4.5 \mathrm{~b}$ & $5.4 \mathrm{a}$ & $6.0 \mathrm{a}$ & $5.2 \mathrm{a}$ & $3.9 \mathrm{c}$ & $5.0 \mathrm{a}$ \\
\hline 250 & $5.5 \mathrm{a}$ & $4.1 \mathrm{~b}$ & $3.4 \mathrm{c}$ & $4.4 \mathrm{~b}$ & $5.1 \mathrm{ab}$ & $4.4 \mathrm{bc}$ & $3.2 \mathrm{~d}$ & $4.2 \mathrm{~b}$ \\
\hline 350 & $4.0 \mathrm{bc}$ & $2.7 \mathrm{~d}$ & $2.6 \mathrm{~d}$ & $3.1 \mathrm{c}$ & $4.2 \mathrm{bc}$ & $4.1 \mathrm{bc}$ & $2.7 \mathrm{~d}$ & $3.7 \mathrm{c}$ \\
\hline 450 & $2.6 \mathrm{~d}$ & $1.8 \mathrm{e}$ & $1.0 \mathrm{f}$ & $1.8 \mathrm{~d}$ & $2.7 \mathrm{~d}$ & $2.0 \mathrm{e}$ & $1.0 \mathrm{f}$ & $1.9 \mathrm{~d}$ \\
\hline 550 & $1.6 \mathrm{ef}$ & $1.0 \mathrm{f}$ & $0.9 \mathrm{f}$ & $1.2 \mathrm{e}$ & $1.5 \mathrm{ef}$ & $1.0 \mathrm{f}$ & $1.0 \mathrm{f}$ & $1.2 \mathrm{e}$ \\
\hline Mean & $4.0 \mathrm{a}$ & $3.1 \mathrm{~b}$ & $2.5 \mathrm{c}$ & & $3.9 \mathrm{a}$ & $3.3 \mathrm{~b}$ & $2.4 \mathrm{c}$ & \\
\hline \multicolumn{9}{|c|}{ Number of spikes per plant } \\
\hline 150 & $5.6 \mathrm{a}$ & $4.9 \mathrm{a}$ & $3.3 \mathrm{~cd}$ & $4.6 \mathrm{a}$ & $5.7 \mathrm{a}$ & $4.5 \mathrm{~b}$ & $2.9 \mathrm{de}$ & $4.4 \mathrm{a}$ \\
\hline 250 & $4.9 \mathrm{a}$ & $4.1 \mathrm{~b}$ & $3.1 \mathrm{~d}$ & $4.0 \mathrm{~b}$ & $4.6 \mathrm{~b}$ & $3.8 \mathrm{c}$ & $2.7 \mathrm{e}$ & $3.7 \mathrm{~b}$ \\
\hline 350 & $3.7 \mathrm{c}$ & $2.7 \mathrm{e}$ & $2.3 \mathrm{f}$ & $2.9 \mathrm{c}$ & $3.5 \mathrm{~cd}$ & $3.1 \mathrm{~d}$ & $2.4 \mathrm{f}$ & $3.0 \mathrm{c}$ \\
\hline 450 & $2.1 \mathrm{fg}$ & $1.8 \mathrm{~g}$ & $1.0 \mathrm{~h}$ & $1.6 \mathrm{~d}$ & $1.8 \mathrm{~g}$ & $1.4 \mathrm{gh}$ & $1.0 \mathrm{~h}$ & $1.4 \mathrm{~d}$ \\
\hline 550 & $1.1 \mathrm{~h}$ & $1.0 \mathrm{~h}$ & $1.0 \mathrm{~h}$ & $1.1 \mathrm{e}$ & $1.0 \mathrm{~h}$ & $1.0 \mathrm{~h}$ & $1.0 \mathrm{~h}$ & $1.0 \mathrm{e}$ \\
\hline Mean & $3.5 \mathrm{a}$ & $2.9 \mathrm{~b}$ & $2.1 \mathrm{c}$ & & $3.3 \mathrm{a}$ & $2.8 \mathrm{~b}$ & $2.0 \mathrm{c}$ & \\
\hline
\end{tabular}

Means followed by the same letter are not significantly different from one to another based on Duncan's test at P 0.05. 
Table (3): Effects of irrigation rate, seeding rate and their interactions on selected yield components and grain yield in two growing seasons.

\begin{tabular}{|c|c|c|c|c|c|c|c|c|}
\hline \multirow{3}{*}{$\begin{array}{l}\text { Seeding rates } \\
\left(\operatorname{seeds} / \mathbf{m}^{2}\right)\end{array}$} & \multicolumn{4}{|c|}{$2013 / 2014$} & \multicolumn{4}{|c|}{$2014 / 2015$} \\
\hline & \multicolumn{8}{|c|}{ Irrigation rates } \\
\hline & $\begin{array}{c}1.00 \mathrm{ET} \\
\left(\mathrm{I}_{1}\right)\end{array}$ & $\begin{array}{c}0.75 E T \\
\left(I_{2}\right)\end{array}$ & $\begin{array}{c}0.50 \text { ET } \\
\left(I_{3}\right)\end{array}$ & Mean & $\begin{array}{c}1.00 \mathrm{ET} \\
\left(\mathrm{I}_{1}\right)\end{array}$ & $\begin{array}{c}0.75 E T \\
\left(I_{2}\right)\end{array}$ & $\begin{array}{c}0.50 \text { ET } \\
\left(I_{3}\right)\end{array}$ & Mean \\
\hline \multicolumn{9}{|c|}{ Number of grains per spike } \\
\hline 150 & $50.4 \mathrm{a}$ & $46.6 \mathrm{a}$ & $38.1 \mathrm{~cd}$ & $45.0 \mathrm{a}$ & $51.4 \mathrm{a}$ & 49.6 a & $38.8 \mathrm{f}$ & 46.6 a \\
\hline 250 & $49.5 \mathrm{a}$ & $46.1 \mathrm{a}$ & $37.9 \mathrm{~cd}$ & $44.5 \mathrm{a}$ & $51.1 \mathrm{a}$ & $46.0 \mathrm{~b}$ & $38.6 \mathrm{f}$ & $45.2 \mathrm{~b}$ \\
\hline 350 & $48.4 \mathrm{a}$ & $42.4 \mathrm{~b}$ & $35.2 \mathrm{e}$ & $42.0 \mathrm{~b}$ & 50.9 a & $44.6 \mathrm{c}$ & $36.4 \mathrm{~g}$ & $44.0 \mathrm{c}$ \\
\hline 450 & $45.0 \mathrm{a}$ & $41.9 \mathrm{~b}$ & $29.8 \mathrm{f}$ & 38.9 c & 50.8 a & $39.9 \mathrm{e}$ & $25.0 \mathrm{i}$ & $38.6 \mathrm{~d}$ \\
\hline 550 & $39.9 \mathrm{bc}$ & $37.0 \mathrm{~d}$ & $23.8 \mathrm{~g}$ & $33.6 \mathrm{~d}$ & $42.8 \mathrm{~d}$ & $34.7 \mathrm{~h}$ & $23.1 \mathrm{j}$ & $33.5 \mathrm{e}$ \\
\hline Mean & $46.6 \mathrm{a}$ & $42.8 \mathrm{~b}$ & $33.0 \mathrm{c}$ & & $49.4 \mathrm{a}$ & $43.0 \mathrm{~b}$ & $32.4 \mathrm{c}$ & \\
\hline \multicolumn{9}{|c|}{ 1000-grains weight (g) } \\
\hline 150 & $58.4 \mathrm{a}$ & $54.1 \mathrm{~b}$ & $42.4 \mathrm{de}$ & 51.6 a & $57.8 \mathrm{a}$ & $52.2 \mathrm{bc}$ & $45.5 \mathrm{e}$ & 51.8 a \\
\hline 250 & $54.3 \mathrm{~b}$ & $53.2 \mathrm{~b}$ & $43.5 \mathrm{~d}$ & $50.3 \mathrm{ab}$ & $56.3 \mathrm{a}$ & $52.4 \mathrm{bc}$ & $43.9 \mathrm{e}$ & 50.9 a \\
\hline 350 & $53.2 \mathrm{~b}$ & $51.8 \mathrm{~b}$ & $41.7 \mathrm{e}$ & $48.9 \mathrm{~b}$ & $54.8 \mathrm{ab}$ & $50.5 \mathrm{~cd}$ & $41.6 \mathrm{f}$ & $49.0 \mathrm{~b}$ \\
\hline 450 & $51.4 \mathrm{~b}$ & $46.9 \mathrm{c}$ & $39.4 \mathrm{f}$ & $45.9 \mathrm{c}$ & $50.5 \mathrm{~cd}$ & $48.5 \mathrm{~d}$ & $36.0 \mathrm{~g}$ & $45.0 \mathrm{c}$ \\
\hline 550 & $46.9 \mathrm{c}$ & $44.0 \mathrm{~d}$ & $36.9 \mathrm{~g}$ & $42.6 \mathrm{~d}$ & $48.5 \mathrm{~d}$ & $44.3 \mathrm{e}$ & $35.8 \mathrm{~g}$ & $42.9 \mathrm{~d}$ \\
\hline Mean & 52.8 a & $50.0 \mathrm{~b}$ & $40.8 \mathrm{c}$ & & 53.6 a & $49.6 \mathrm{~b}$ & $40.6 \mathrm{c}$ & \\
\hline \multicolumn{9}{|c|}{ Grain yield (ton/ha) } \\
\hline 150 & $1.77 \mathrm{fg}$ & $1.73 \mathrm{~g}$ & $1.61 \mathrm{~g}$ & $1.71 \mathrm{~d}$ & $2.73 \mathrm{ef}$ & $2.00 \mathrm{f}$ & $1.90 \mathrm{f}$ & $2.21 \mathrm{~d}$ \\
\hline 250 & $4.76 \mathrm{~b}$ & $3.89 \mathrm{c}$ & $2.19 \mathrm{f}$ & $3.62 \mathrm{~b}$ & $5.59 \mathrm{~b}$ & $4.65 \mathrm{c}$ & $3.05 \mathrm{e}$ & $4.43 \mathrm{~b}$ \\
\hline 350 & $6.38 \mathrm{a}$ & $4.94 \mathrm{~b}$ & $1.79 \mathrm{fg}$ & $4.37 \mathrm{a}$ & $6.70 \mathrm{a}$ & $5.25 \mathrm{~b}$ & $2.64 \mathrm{f}$ & $4.87 \mathrm{a}$ \\
\hline 450 & $6.30 \mathrm{a}$ & $3.59 \mathrm{~d}$ & $1.78 \mathrm{fg}$ & $3.89 \mathrm{~b}$ & $6.64 \mathrm{a}$ & $4.64 \mathrm{c}$ & $2.57 \mathrm{f}$ & $4.61 \mathrm{ab}$ \\
\hline 550 & $5.22 \mathrm{~b}$ & $3.25 \mathrm{e}$ & $1.50 \mathrm{~g}$ & $3.32 \mathrm{c}$ & $5.68 \mathrm{~b}$ & $3.70 \mathrm{~d}$ & $2.15 \mathrm{f}$ & $3.84 \mathrm{c}$ \\
\hline Mean & $4.89 \mathrm{a}$ & $3.48 \mathrm{~b}$ & $1.78 \mathrm{c}$ & & $5.47 \mathrm{a}$ & $4.05 \mathrm{~b}$ & $2.46 \mathrm{c}$ & \\
\hline
\end{tabular}


Grain yield and its components were also influenced by seeding rates. All yield components was gradually and significantly decreased as seeding rates increased, whereas the final grain yield per hectare was significantly increased with increasing seeding rate up to 350 seeds $/ \mathrm{m}^{2}$ and thereafter slightly decreased at 450 seeds $/ \mathrm{m}^{2}$ (Tables 2 and 3 ). In general, the highest and lowest values for plant height and yield components of individual plants were obtained with 150 and 550 seeds $/ \mathrm{m}^{2}$, respectively. Whereas, the highest grain yield per hectare was observed at $350 \mathrm{seeds} / \mathrm{m}^{2}$ followed by 450 and $250 \mathrm{seeds} / \mathrm{m}^{2}$ and the lowest values for grain yield was obtained at 150 seeds $/ \mathrm{m}^{2}$ (Tables 2 and 3 ). These results indicate that the production of individual plants becomes a limiting factor for maximize final grain yield under high seeding rates and the compensatory relations among yield components is almost absent; probably because of maximize plant-toplant competition. Although the inverse is true under very low seeding rates as found at $150 \mathrm{seeds} / \mathrm{m}^{2}$ in this study, the production of individual plants are not sufficient to compensate the reduction in number of plants per unit area. Thus, the final grain yield becomes a limiting factor under very low seeding rates (Awad et al., 2013; Al-Suhaibani et al., 2013).

The irrigation rate and seeding density interaction had a significant effect on final grain yield and its components in both growing seasons (Tables 2 and 3). In general, the response of yield components and grain yield for irrigation rates dependent on plant density. For instance, the values of yield components obtained from the combination of 0.75 ET $(25.0 \%$ reduction in water applied) with low seeding rate were comparable with those of the combination of 1.00 ET with medium seeding rates $\left(250\right.$ and 350 seeds $\left./ \mathrm{m}^{2}\right)$. The grain yield of the combination of 0.75 ET with 350 seeds $/ \mathrm{m}^{2}$ was comparable with those of the combination of $1.00 \mathrm{ET}$ with 250 or 550 seeds $/ \mathrm{m}^{2}$. The values of grain yield for the combination of 0.50 ET $(50.0 \%$ reduction in water applied) with 350 seeds $/ \mathrm{m}^{2}$ was higher than those of the combination of $1.00 \mathrm{ET}$ or $0.75 \mathrm{ET}$ with low seeding rates $\left(150\right.$ seeds $\left./ \mathrm{m}^{2}\right)$ (Tables 3 and 4$)$. These results indicate that the production of wheat under deficit irrigation requires the necessity for decreasing seeding rate compared with those produced under full irrigation conditions. This was because the low seeding rate under limited water application provides more water and nutrients per plant compared with high seeding rate. Ali et al. (2007) and Hu et al. (2015) reported that the lower ET at low seeding rate compared with high seeding rate reflects less water requirement.

\section{Biological yield and harvest index}

The data in Table (4) showed that the values of biological yield and harvest index (HI) were gradually decreased by decreasing irrigation rate. The highest seeding rates (450 and 550 seeds $/ \mathrm{m}^{2}$ ) produced the highest value for biological yield per hectare. Whereas, the highest value for HI was obtained from the medium seeding rates $\left(250\right.$ and 350 seeds $\left./ \mathrm{m}^{2}\right)$. Interestingly, the interaction between irrigation rate and seeding rate had a significant effect on both traits (Table 4). For biological yield, the value of this trait at the combination of high seeding rate with deficit irrigation was always comparable with those of the combination of low seeding rate with full irrigation. However, the highest values for HI were always obtained from the combinations of seeding rates at 250,350 or 450 seeds $/ \mathrm{m}^{2}$ with 1.00 or $0.75 \mathrm{ET}$ (Table 4 ). These results clearly indicate that the translocation process towards the sink was affected adversely by very low or high seeding rates and it more significantly correlated with grain yield than straw yield. These findings are in agreement with those of Arduini et al. (2006), Ali et al. (2010), and Abd El-Lattief (2014), who found significantly relationships between $\mathrm{HI}$ and the balance between grain yield and straw yield under different agronomic treatments.

\section{Irrigation water use efficiency}

High or medium irrigation rate $(1.00$ or $0.75 \mathrm{ET})$ and medium seeding rate $\left(350 \mathrm{seeds} / \mathrm{m}^{2}\right)$ displayed the highest value for irrigation water use efficiency (IWUE) in both seasons (Table 4). Interestingly, the values of IWUE, especially in the second season, at the combinations of very low irrigation rate $(0.50 \mathrm{ET})$ with 250 seeds $/ \mathrm{m}^{2}$ were comparable with those the combinations of high irrigation rate $(1.00$ ET) or medium irrigation rate $(0.75 \mathrm{ET})$ with medium or high seeding rates. The lowest IWUE was recorded for the combination of 1.00 or 0.75 ET with 150 seeds $/ \mathrm{m}^{2}$ (Table 4). This finding indicates that deficit irrigation can effectively supported IWUE under low seeding rate. In addition, although the irrigation rate is vitally important for supporting IWUE, plant density is also play an important role for maximizing net income per unit water (Zhang et al., 2004; El-Hendawy et al., 2008).

\section{Yield response factor $(\mathrm{ky})$}

Doorenbos and Kassam, (1979) used the value of ky to understand the relationship between the relative grain yield decrease $\left(1-\mathrm{Y}_{\mathrm{a}} / \mathrm{Y}_{\mathrm{m}}\right)$ and the corresponding relative water deficit $\left(1-\mathrm{ET}_{\mathrm{a}} / \mathrm{ET}_{\mathrm{m}}\right)$. In general, if the ky value is greater than 1 , this indicate that the reduction in final grain yield is great and most sensitive to water deficit. However, if the ky value is less than 1 , the reduction in final grain yield is less sensitive to water deficit (Kirda, 2002). In this study, the lowest ky value for medium irrigation rate $(0.75 \mathrm{ET})$ was obtained when it combined with $350 \mathrm{seeds} / \mathrm{m}^{2}$, whereas for the low irrigation rate $(0.50 \mathrm{ET})$, it was obtained when combined with 250 seeds $/ \mathrm{m}^{2}$ (Table 5). This finding indicates that the reduction in grain yield under deficit irrigation practices could be acceptable when they combined with moderate seeding rate. In addition, the combined of 0.75 or 0.50 ET with very low or high seeding rates always produced the highest values for ky (Table 5). This result may be due to the high competition between plants under high seeding rate and the ability of production of individual plant under low seeding rate doesn't compensate the reduction in number of plants per unit area leads to decrease the final grain yield per unit area and therefore increase the value of ky. 


\section{Production functions}

The relationship of grain yield with the irrigation and seeding rates were used in order to develop the production functions for both treatments. In general, the best relationship between grain yield and the irrigation rate was linear and significant with intermediate coefficient of determination $\left(\mathrm{R}^{2}=0.54\right.$ and 0.53$)$ in first and second season, respectively (Fig. 1). However, the second order relationship was found as the best model described the relationship between grain yield and seeding rates (Fig. 2). In addition, the regression between grain yield and seeding rate showed a second order relationship for each irrigation rate with high coefficient of determination for $1.00 \mathrm{ET}\left(\mathrm{R}^{2}=0.99\right.$ and $0.96)$ and for $0.75 \mathrm{ET}\left(\mathrm{R}^{2}=0.79\right.$ and 0.84$)$ and intermediate coefficient of determination for $0.50 \mathrm{ET}$ $\left(\mathrm{R}^{2}=0.31\right.$ and 0.53$)$ in the first and second season, respectively (Fig. 3).

Table (4): Effects of irrigation rate, seeding rate and their interactions on biological yield, harvest index and irrigation water use efficiency in two growing seasons

\begin{tabular}{|c|c|c|c|c|c|c|c|c|}
\hline \multirow{3}{*}{$\begin{array}{l}\text { Seeding rates } \\
\left(\text { seeds } / \mathbf{m}^{2}\right)\end{array}$} & \multicolumn{4}{|c|}{$2013 / 2014$} & \multicolumn{4}{|c|}{$2014 / 2015$} \\
\hline & \multicolumn{8}{|c|}{ Irrigation rates } \\
\hline & $\begin{array}{c}1.00 \mathrm{ET} \\
\left(\mathrm{I}_{1}\right)\end{array}$ & $\begin{array}{c}0.75 E T \\
\left(I_{2}\right)\end{array}$ & $\begin{array}{c}0.50 \text { ET } \\
\left(I_{3}\right)\end{array}$ & Mean & $\begin{array}{c}1.00 \mathrm{ET} \\
\left(\mathrm{I}_{1}\right)\end{array}$ & $\begin{array}{c}\text { 0.75ET } \\
\left(\mathrm{I}_{2}\right)\end{array}$ & $\begin{array}{c}0.50 \text { ET } \\
\left(I_{3}\right)\end{array}$ & Mean \\
\hline \multicolumn{9}{|c|}{ Biological yield (ton $\mathrm{ha}^{-1}$ ) } \\
\hline 150 & $8.72 \mathrm{c}$ & $7.06 \mathrm{~d}$ & $5.73 \mathrm{e}$ & $7.17 \mathrm{c}$ & $8.50 \mathrm{~cd}$ & $7.50 \mathrm{de}$ & $5.50 \mathrm{~g}$ & $7.17 \mathrm{c}$ \\
\hline 250 & $9.96 \mathrm{c}$ & $8.91 \mathrm{c}$ & $6.64 \mathrm{~d}$ & $8.50 \mathrm{~b}$ & $9.99 \mathrm{c}$ & $8.99 \mathrm{c}$ & 7.05 ef & $8.67 \mathrm{~b}$ \\
\hline 350 & $11.91 \mathrm{~b}$ & $10.02 \mathrm{c}$ & $6.70 \mathrm{~d}$ & $9.54 \mathrm{a}$ & $11.83 \mathrm{~b}$ & $9.73 \mathrm{c}$ & $6.88 \mathrm{ef}$ & $9.48 \mathrm{a}$ \\
\hline 450 & $12.67 \mathrm{a}$ & $9.90 \mathrm{c}$ & $6.73 \mathrm{~d}$ & $9.76 \mathrm{a}$ & $13.08 \mathrm{a}$ & $9.63 \mathrm{c}$ & $6.90 \mathrm{ef}$ & $9.87 \mathrm{a}$ \\
\hline 550 & $13.18 \mathrm{a}$ & $9.82 \mathrm{c}$ & $6.97 \mathrm{~d}$ & $9.99 \mathrm{a}$ & $13.16 \mathrm{a}$ & $9.70 \mathrm{c}$ & $6.80 \mathrm{f}$ & $9.88 \mathrm{a}$ \\
\hline Mean & $11.29 \mathrm{a}$ & $9.14 \mathrm{~b}$ & $6.55 \mathrm{c}$ & & $11.31 \mathrm{a}$ & $9.11 \mathrm{~b}$ & $6.63 \mathrm{c}$ & \\
\hline \multicolumn{9}{|c|}{ Harvest index (\%) } \\
\hline 150 & $20.4 \mathrm{e}$ & $24.5 \mathrm{e}$ & $28.0 \mathrm{e}$ & $24.3 \mathrm{~d}$ & 31.9 cde & $26.6 \mathrm{e}$ & $34.9 \mathrm{~cd}$ & $31.1 \mathrm{~d}$ \\
\hline 250 & $47.8 \mathrm{ab}$ & $43.7 \mathrm{~b}$ & $32.8 \mathrm{~d}$ & $41.4 \mathrm{a}$ & $55.9 \mathrm{a}$ & $51.7 \mathrm{a}$ & $43.3 \mathrm{c}$ & $50.3 \mathrm{a}$ \\
\hline 350 & $53.7 \mathrm{a}$ & $49.3 \mathrm{a}$ & $26.8 \mathrm{e}$ & $43.2 \mathrm{a}$ & $56.7 \mathrm{a}$ & $54.0 \mathrm{a}$ & $38.5 \mathrm{c}$ & $49.7 \mathrm{a}$ \\
\hline 450 & $49.7 \mathrm{a}$ & $36.2 \mathrm{~cd}$ & $26.4 \mathrm{e}$ & $37.5 \mathrm{~b}$ & $50.8 \mathrm{ab}$ & $48.2 \mathrm{ab}$ & $37.2 \mathrm{c}$ & $45.4 \mathrm{~b}$ \\
\hline 550 & $39.7 \mathrm{c}$ & $33.1 \mathrm{~d}$ & $21.7 \mathrm{e}$ & $31.5 \mathrm{c}$ & $43.5 \mathrm{bc}$ & $38.2 \mathrm{c}$ & $31.6 \mathrm{de}$ & $37.8 \mathrm{c}$ \\
\hline Mean & $42.3 \mathrm{a}$ & $37.4 \mathrm{~b}$ & $27.1 \mathrm{c}$ & & $47.7 \mathrm{a}$ & $43.7 \mathrm{~b}$ & $37.1 \mathrm{c}$ & \\
\hline \multicolumn{9}{|c|}{ Irrigation water use efficiency $\left(\mathrm{kg} \mathrm{mm}^{-1}\right)$} \\
\hline 150 & $2.84 \mathrm{f}$ & $3.69 \mathrm{f}$ & $5.16 \mathrm{de}$ & $3.90 \mathrm{~d}$ & 4.36 ef & $4.26 \mathrm{f}$ & $6.09 \mathrm{e}$ & $4.91 \mathrm{c}$ \\
\hline 250 & $7.62 \mathrm{bc}$ & $8.31 \mathrm{~b}$ & $7.02 \mathrm{c}$ & $7.65 \mathrm{~b}$ & $8.94 \mathrm{bc}$ & $9.93 \mathrm{~b}$ & $9.76 \mathrm{~b}$ & $9.54 \mathrm{a}$ \\
\hline 350 & $10.20 \mathrm{a}$ & $10.54 \mathrm{a}$ & $5.73 \mathrm{~d}$ & 8.82 a & $10.73 \mathrm{ab}$ & $11.20 \mathrm{a}$ & $8.46 \mathrm{c}$ & $10.13 \mathrm{a}$ \\
\hline 450 & $10.07 \mathrm{a}$ & $7.66 \mathrm{bc}$ & $5.70 \mathrm{~d}$ & $7.81 \mathrm{~b}$ & $10.62 \mathrm{ab}$ & $9.89 \mathrm{~b}$ & $8.21 \mathrm{c}$ & $9.58 \mathrm{a}$ \\
\hline 550 & $8.36 \mathrm{~b}$ & $6.93 \mathrm{c}$ & $4.80 \mathrm{e}$ & $6.69 \mathrm{c}$ & $9.09 \mathrm{bc}$ & $7.90 \mathrm{c}$ & $6.87 \mathrm{~d}$ & $7.96 \mathrm{~b}$ \\
\hline Mean & $7.82 \mathrm{a}$ & $7.42 \mathrm{a}$ & $5.68 \mathrm{~b}$ & & $8.75 \mathrm{a}$ & $8.64 \mathrm{a}$ & $7.88 \mathrm{~b}$ & \\
\hline
\end{tabular}

Means followed by the same letter are not significantly different from one another based on Duncan's test at P 0.05 . 
Table (5): Yield response factor (ky) for the combination between irrigation rates $(0.75$ and 0.50 ET) and different seeding rates in two growing seasons.

\begin{tabular}{|c|c|c|c|c|c|c|c|}
\hline \multirow{2}{*}{. } & \multirow{2}{*}{ 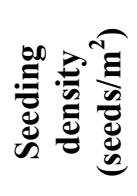 } & \multicolumn{3}{|c|}{$2013 / 2014$} & \multicolumn{3}{|c|}{$2014 / 2015$} \\
\hline & & $1-\left(\mathbf{E T}_{\mathrm{a}} / \mathbf{E T}_{\mathrm{m}}\right)$ & $1-\left(Y_{a} / Y_{m}\right)$ & ky & $\begin{array}{c}1- \\
\left(\mathbf{E T}_{\mathrm{a}} / \mathbf{E T}_{\mathrm{m}}\right)\end{array}$ & $1-\left(Y_{a} / Y_{m}\right)$ & ky \\
\hline \multirow{5}{*}{ 0.75 ET } & 150 & 0.25 & 0.73 & 2.91 & 0.25 & 0.70 & 2.81 \\
\hline & 250 & 0.25 & 0.39 & 1.56 & 0.25 & 0.31 & 1.22 \\
\hline & 350 & 0.25 & 0.23 & 0.90 & 0.25 & 0.22 & 0.87 \\
\hline & 450 & 0.25 & 0.44 & 1.75 & 0.25 & 0.31 & 1.23 \\
\hline & $\mathbf{5 5 0}$ & 0.25 & 0.49 & 1.96 & 0.25 & 0.45 & 1.79 \\
\hline \multirow{5}{*}{0.50 ET } & 150 & 0.50 & 0.75 & 1.49 & 0.50 & 0.72 & 1.43 \\
\hline & 250 & 0.50 & 0.66 & 1.31 & 0.50 & 0.55 & 1.09 \\
\hline & 350 & 0.50 & 0.72 & 1.44 & 0.50 & 0.61 & 1.21 \\
\hline & 450 & 0.50 & 0.72 & 1.44 & 0.50 & 0.62 & 1.23 \\
\hline & 550 & 0.50 & 0.76 & 1.53 & 0.50 & 0.68 & 1.36 \\
\hline
\end{tabular}

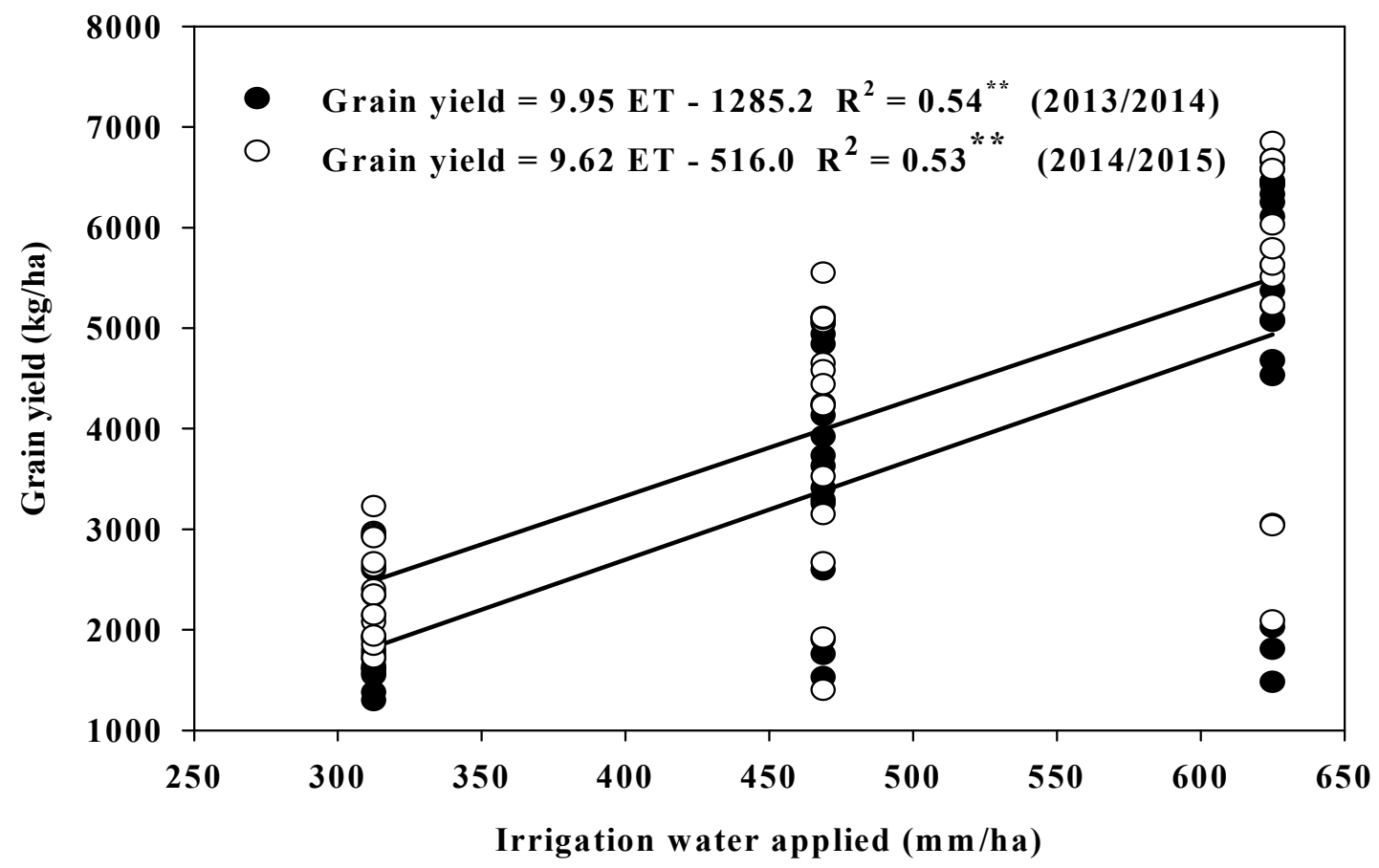

Fig. (1): Relationship between grain yield and irrigation water applied. Linear regression equations (** indicates significance at $\mathrm{P} \leq 0.05)$. 


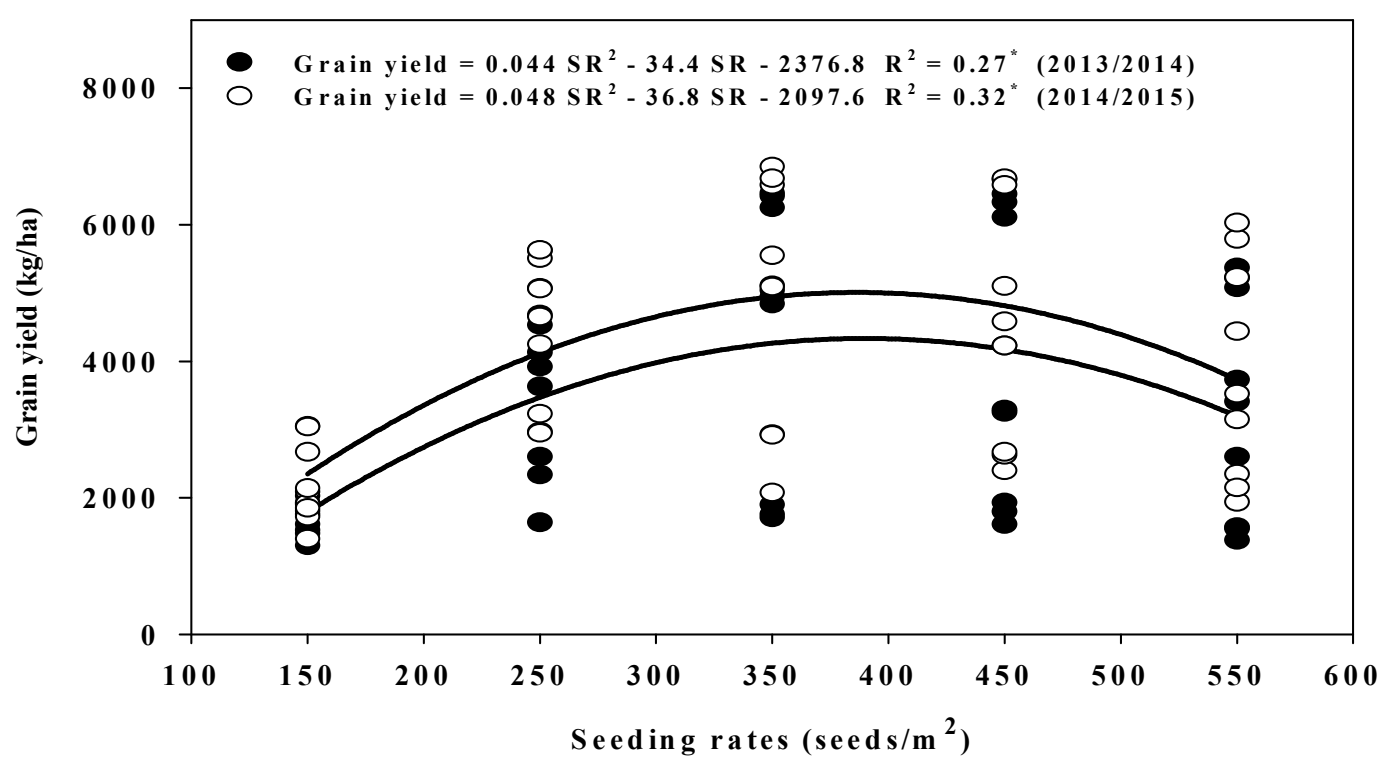

Fig. (2): Relationship between grain yield and seeding rates. A regression equations (* indicates significance at $\mathrm{P} \leq 0.05)$.

Based on the equations in Fig. (1), the basal amount of irrigation water needed to initiate grain yield irrespective of seeding rates was determined to be 129.2 and $53.6 \mathrm{~mm}$ and after that the increase in grain yield for each unit increase in water applied were 9.95 and $9.62 \mathrm{~kg} / \mathrm{mm}^{1}$ in the first and second season, respectively. The yield relationship to seasonal ET for wheat has been reported as linear by Musick et al. (1994), Zhang et al. (1999), and Huang et al. (2004) with an increase in grain yield for each unit increase in water applied by $12.2,10.0$ and $11.2 \mathrm{~kg} / \mathrm{mm}^{1}$, respectively.
Based on the equations in Fig. (2), the optimum seeding rate for the maximum grain yield irrespective of irrigation rates was 391 and 383 seeds $/ \mathrm{m}^{2}$ in the first and second season, respectively. The both values were obtained by taking the first derivation of each equation reported in Fig. (2) and equalizing to zero. However, the optimum seeding rate for the maximum grain yield were 411 and 425 seeds $/ \mathrm{m}^{2}$ for $1.00 \mathrm{ET}, 362$ and 378 seeds $/ \mathrm{m}^{2}$ for $0.75 \mathrm{ET}$ and 315 and 350 seeds $/ \mathrm{m}^{2}$ for $0.50 \mathrm{ET}$ in the first and second season, respectively (Fig. 3).

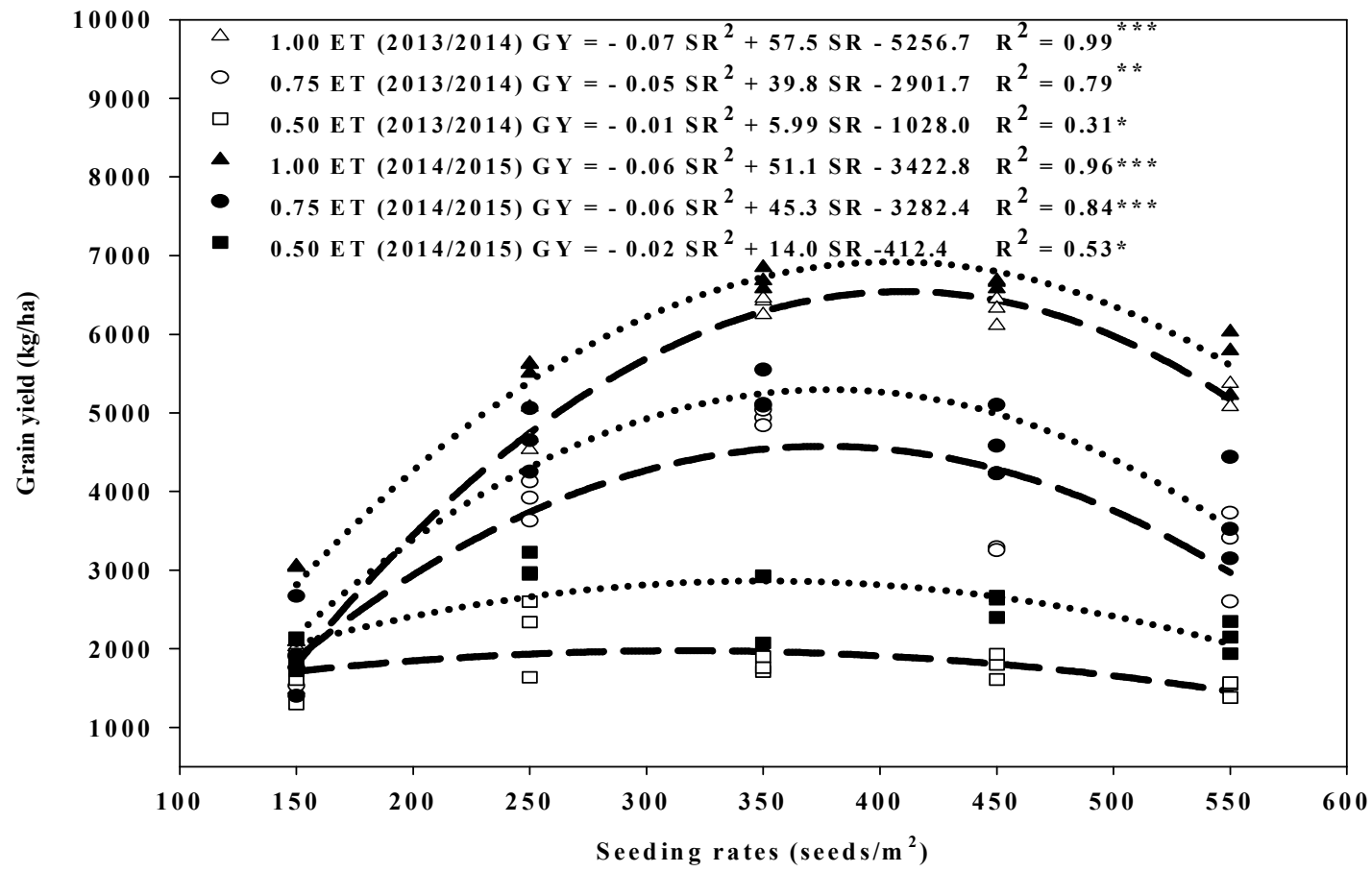

Fig. (3): Relationship between grain yield (GY) and seeding rates (SR) for each of three irrigation rate in two growing seasons. Regression equations $(*, * *, * * *$ indicate significance at $\mathrm{P} \leq 0.05,0.01$ and 0.001 , respectively). 


\section{CONCLUSION}

These results indicate that it is important to determine the optimal coupling combinations between irrigation and seeding rates to achieve the maximum grain yield of wheat. It is appear that it is important to decrease seeding rate under deficit irrigation and vice versa where the irrigation water is not limited factor for wheat production.

\section{REFERENCES}

Abd El-Lattief, E. A. (2014) Determining the optimization seeding rate for improved productivity of wheat under Southern Egypt conditions. Inter. J. Agron. Agri. Res., 4 (1): $47-$ 57.

Ali, A. G., O. E. Zeiton, A. H. Bassiauny and A. R. Y. El- Banna (2004). Productivity of wheat cultivars grown at El- Khattara and El-Arish under different levels of planting densities and $\mathrm{N}$ fertilization. Zagazig J. Agric. Res., 31: 12251256.

Ali, M. H., M. R. Hoque, A. A. Hassan and A. Khair (2007). Effects of deficit irrigation on yield, water productivity, and economic returns of wheat. Agric Water Manage., 92: 151-161.

Ali, M., L. Ali, M. Sattar and M. A. Ali (2010). Improvement in wheat (Triticum aestivum L.) yield by manipulating seed rate and row spacing in Vehai zone. J. Animal and Plant Sci., 20: 225230.

Allen, R. G, L. S. Pereira, D. Raes and M. Smith (1998). Crop evapotranspiration guidelines for computing crop water requirements. (Irrigation and drainage paper 56) FAO of the United Nations, Rome, Italy.

Arduini, I., A. Masoni, L. Ercoli and M. Mariotti (2006). Grain yield, and dry matter and nitrogen accumulation and remobilization in durum wheat as affected by variety and seeding rate. Europ. J. Agron., 25: 309-318

Al-Suhaibani, N., S. E. El-Hendawy and U. Schmidhalter (2013). Influence of varied plant density on growth, yield and economic return of drip irrigated faba bean (Vicia faba L.). Turkish J. Field Crops, 18(2): 185-197.

Awad, A, S. Hafiz, M. S. Hmmada, A. El-nouby and S. E. El-hendawy (2013). Grain yield production of Sudan grass (Sorghum sudanense (Piper) Stapf) as influenced by cutting numbers, potassium rates, and intrarow spacing in a semiarid environment. Turk. J. Agric. For., 37: 657-664

Boutraa, T. (2010). Improvement of water use efficiency in irrigated agriculture: A review. J. Agron., 9: 1-8.

Chen, C., K. Neill, D. Wichman and M. Westcott (2008). Hard red spring wheat response to row spacing, seeding rate, and nitrogen. Agron. J., 100: 1296-1302.

Doorenbos, J. and A. H. Kassam (1979). Yield response to water. FAO Irrigation and Drainage Paper 33. Rome, Italy: UN-FAO.
El-Hendawy, S. E, E. A. A. El-Lattief, M. S. Ahmed and U. Schmidhalter (2008). Irrigation rate and plant density effects on yield and water use efficiency of drip-irrigated corn. Agric. Water Manage., 95: 836-844.

Fereres, E. and M. A. Sorianoz (2007). Deficit irrigation for reducing agricultural water use. J. Exp. Bot., 58: $147-159$.

Hu, C., M. Ding, C. Qu, V. Sadras, X. Yang and S. Zhang (2015). Yield and water use efficiency of wheat in the Loess Plateau: Responses to root pruning and defoliation. Field Crops Res., 179: 6-11.

Huang, Y., L. Chen, B. Fu, Z. Huang and J. Gong (2004). The wheat yields and water-use efficiency in the Loess Plateau: straw mulch and irrigation effects. Agric. Water Manage., 67: 5568.

Karam, F., R. Kabalan J. Breidi, Y. Rouphael and T. Oweis (2009). Yield and water-production functions of two durum wheat cultivars grown under different irrigation and nitrogen regimes. Agric. Water Manage., 96: 603-615.

Kirda, C. (2002). Deficit irrigation scheduling based on plant growth stages showing water stress tolerance. In: Deficit Irrigation Practice. Water reports 22, 1-3. Kirda, C. (Ed.), FAO.

Kramer, P. J. and J. S. Boyer (1995). Water relations of plant and soils. Academic Press, San Diego.

Li, F.S, C.H. Wei, F.C. Zhang, J.H. Zhang, M.L. Nong and S.Z. Kang (2010). Water-use efficiency and physiological responses of maize under partial root-zone irrigation. Agric. Water Manage., 97: 1156-1164.

M'hamed, H. C, M. Rezig and B. N. Mbarek (2015). Water use efficiency of durum wheat (Triticum durum Desf) under deficit irrigation. J. Agric. Sci., 7 (8): 238-249.

Morison J. I, N. R. Baker, P. M. Mullineaux and W. J Davies (2008). Improving water use in crop production. Philo. Trans. Res. Soc. London B Biol. Sci., 12: 639-658.

Mugabe, F. T. and E. Z. Nyakatawa (2000). Effect of deficit irrigation on wheat and opportunities of growing wheat on residual soil moisture in southeast Zimbabwe. Agric. Water Manage., 46: 111-119.

Musick, J. T., O. R. Jones, B. A. Stewart and D. A. Dusek (1994). Water-yield relationships for irrigated and dryland wheat in the U.S. Southern Plains. Agron. J., 86: 980- 986.

Naseri, R., A. Soleymanifard, H. Khoshkhabar, A. Mirzaei and K. Nazaralizadeh (2012). Effect of plant spacing on grain yield and yield components and associated traits of three durum wheat cultivars in western Iran. Intl. J. Agri. Crop Sci., 4: 79-85.

Ouda, S. A. (2006). Predicting the effect of water and salinity stresses on wheat yield and water needs. In. J. Appl. Sci. Res., 2: 750-756.

Ozturk, A., O. Caglar and S. Bulut (2006). Growth and yield response of facultative wheat to winter sowing, freezing sowing and spring sowing at 
different seeding rates. J. Agron. Crop Sci., 192: $10-16$.

Passioura, J. (2006). Increasing crop productivity when water is scarce: From breeding to field management. Agric. Water Manage., 80: 176 196.

Passioura, J. B. and J. F. Angus (2010). Improving productivity of crops in water-limited environments. In. Advan. Agron., 106: 37 - 75.

Ramadan, A. R. and S. S. Awaad (2008). Response of yield and yield attributes of some bread wheat varieties to irrigation levels and seeding rate under old land conditions. In. J. Agri. Sci. Mansoura Univ., 33: 4717 - 4737.

Richards, R. A. (2004). Physiological traits used in the breeding of new cultivars for water-scarce environments. Proceedings of the 4th International Crop Science Congress, Sept. 26Oct. 1, Brisbane, Australia,

Seleiman, M. F., M. E. Ibrahim, S. M. Abdel-Aal and G. A. Zahran (2010). Effect of seeding rates on productivity, technological and rheological characteristics of bread wheat (Triticum aestivum L.). Int. J. Curr. Res., 4: 075 - 081.

Singh, R, D. K. Kundu and K. K. Bandopadhyay (2010). Enhancing agricultural productivity through enhanced water use efficiency. J. Agric. Phys., 10: 1-15.

Soundharajan, B. and K. P. Sudheer (2009). Deficit irrigation management for rice using crop growth simulation model in an optimization framework. Paddy Water Environ., 7: 135-149.

Tompkins, D. K., D. B. Fowler and A. T. Wright (1991). Water use by no-till winter wheat.
Influence of seed rate and row spacing. Agron. J., 83: 766-769.

Valério, I. P., F. I. de Carvalho, G. Benin, G. da Silveira, J. A. G. Silva, R. Nornberg, T. Hagemann, H. Luche and A. C. Oliveira (2013). Seeding density in wheat: the more, the merrier? Sci. Agric., 70 (3): 176-184.

Whaley, J. M., D. L. Sparkes, M. J. Foulkes, J. H. Spink, T. Semere and R. K. Scott (2000). The physiological response of winter wheat to reductions in plant density. Ann. Appl. Biol., 137: $165-178$.

Xue, Q, Z. Zhu, J. T. Musick, B. A. Stewart and D. A. Dusek (2006). Physiological mechanisms contributing to the increased water-use efficiency in winter wheat under deficit irrigation. J. Plant Physiol., 163: 154-164.

Zhang, H., X. Wang, M. You and C. Liu (1999). Wateryield relations and water-use efficiency of winter wheat in the North China Plain. Irrig. Sci., 19: 37-45.

Zhang, Y., E. Kendy, Y. Qiang, L. Changming, S. Yanjun and S. Hongyong (2004). Effect of soil water deficit on evapotranspiration, crop yield, and water use efficiency in the North China Plain. Agric. Water Manage., 64: 107-122.

Zhang, B., F. Li, G. Huang, Z.Y. Cheng and Y. Zhang (2006). Yield performance of spring wheat improved by regulated deficit irrigation in an arid area. Agric. Water Manage., 79: 28-42.

Zhong-hu, H. and S. Rajaram (1994). Differential responses of bread wheat characters to high temperature. Euphytica, 72: 197-203.

Zadoks, J. C, T. T. Chang and C. F. Konzak (1974). A decimal code for the growth stages of cereals. Weeds Res., 14: 412-415.

\section{الاقتران الأمثل بين معدلات الري والتقاوي لتحسين إنتاجية وكفاءة استخدام الماء لمحصول القمح

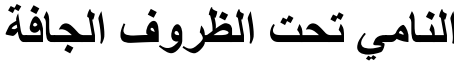 \\ صلاح السبد النهاوي

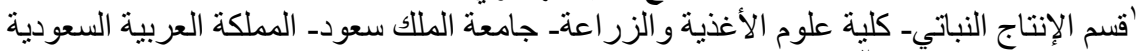



تتز ايد أهمية الاستخدام المستدام للمياه بالنسبة للأمن الغذائي في المناطق الجافة وشبه جافة مع الموارد المائية المحدودة. ولقد أجريت

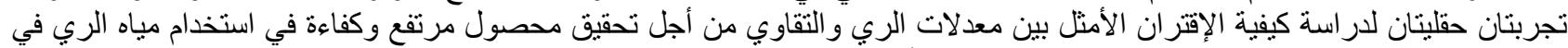

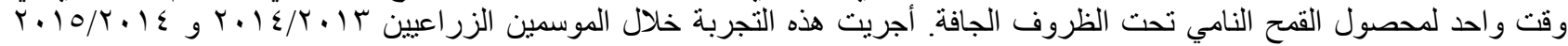

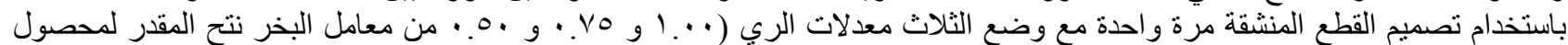

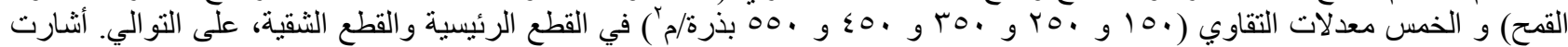

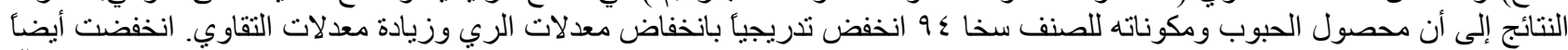



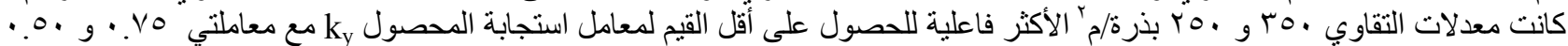

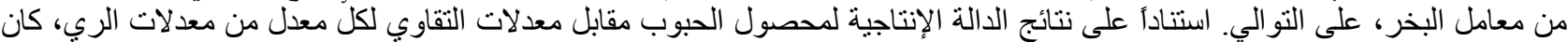

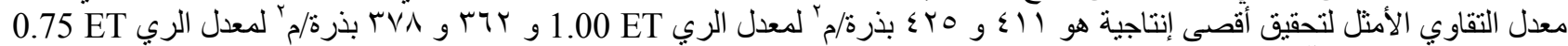

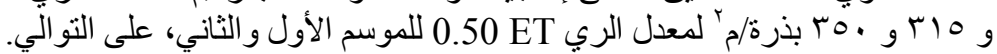
الكلمات الافتتاحية: الري الناقص، دليل الحصاد، دالة إنتاج الماء، معامل استجابة المحصول 